\title{
Correction: Ueoka, I., et al. Autism Spectrum Disorder-Related Syndromes: Modeling with Drosophila and Rodents. Int. J. Mol. Sci. 2019, 20, 4071
}

\author{
Ibuki Ueoka ${ }^{1}$, Hang Thi Nguyet Pham ${ }^{2}$, Kinzo Matsumoto ${ }^{3}$ and Masamitsu Yamaguchi ${ }^{1, *}$ \\ 1 Department of Applied Biology, Kyoto Institute of Technology, Matsugasaki, Sakyo-ku, Kyoto 603-8585, \\ Japan; merry.christmas.ibu@gmail.com \\ 2 Department of Pharmacology and Biochemistry, National Institute of Medicinal Materials, Hanoi 110100, \\ Vietnam; pnhang2004@yahoo.com \\ 3 Division of Medicinal Pharmacology, Institute of Natural Medicine, University of Toyama, Toyama 930-0194, \\ Japan; kinzo.matsumoto@gmail.com \\ * Correspondence: myamaguc8@gmail.com
}

Received: 13 October 2020; Accepted: 19 October 2020; Published: 30 October 2020

The author wishes to make the following correction to this paper [1]. Due to mistakes in numerical values ("Protein coding genes shared with human", "\% of human disease genes conserved", "Neuronal cells/brain", and "Production of offspring/female") in Table 1, it should be replaced with the following table:

Table 1. Comparison of mouse (M. musculus) and Drosophila (D. melanogaster) as model organism.

\begin{tabular}{ccc}
\hline & Mouse & Drosophila \\
\hline Genome size & $2.8 \mathrm{Gbp}$ & $0.14 \mathrm{Gbp}$ \\
\hline Protein coding genes shared with human & $88 \%$ & $58 \%$ \\
\hline$\%$ of human disease genes conserved & $99 \%$ & $75 \%$ \\
\hline Neuronal cells/brain & $7 \times 10^{7}$ & $1.35 \times 10^{5}$ \\
\hline Complex behavior & +++ & + \\
\hline Generation time & 50 days & 10 days \\
\hline Genome-wide genetic screen & + & +++ \\
\hline Production of offspring/female & $10 /$ litter & 100 eggs/day \\
\hline Ethical restriction & +++ & +
\end{tabular}

These changes have no material impact on the conclusions of our paper. The authors apologize for any inconvenience caused to the readers by these changes.

Conflicts of Interest: The authors declare no conflict of interest.

\section{Reference}

1. Ueoka, I.; Pham, H.T.N.; Matsumoto, K.; Yamaguchi, M. Autism Spectrum Disorder-Related Syndromes: Modeling with Drosophila and Rodents. Int. J. Mol. Sci. 2019, 20, 4071. [CrossRef] [PubMed]

Publisher's Note: MDPI stays neutral with regard to jurisdictional claims in published maps and institutional affiliations.

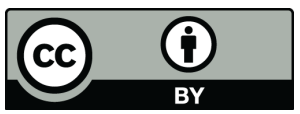

(C) 2020 by the authors. Licensee MDPI, Basel, Switzerland. This article is an open access article distributed under the terms and conditions of the Creative Commons Attribution (CC BY) license (http://creativecommons.org/licenses/by/4.0/). 